\title{
Being One and Two and Druze: Problems of belonging in the remembrance of previous lives
}

\author{
Lorenz NIGST
}

\section{ABSTRACT}

A distinctive feature of the Druze belief-system is the belief in the "transmigration of the soul" (taqammuş). According to the Druze understanding of how transmigration works, dealing with a soul is always tantamount to dealing with a distinct human being because the soul moves to a new body immediately after its previous body has died. While a human being is thus only a transient manifestation of a soul which was, and will be, somewhere else, the present article proposes to take seriously that human beings are involved. At first suspending the notion of taqammus, and falling back on the conceptual framework elaborated by Luc Boltanski in his Foetal Condition, it is suggested that those human beings cannot only be considered as members of groups and objects of classification, but furthermore must be considered in their singularity. Assuming that singularity must be transferred to a human being, the towering importance of a singularisation process becomes apparent that begins before birth and directs the human beings in question towards a name and a unique place in a family. From the perspective of the notion that souls migrate, however, not only does the question arise whether a particular soul is the member of the same groups in its subsequent manifestations; more importantly, the Druze conviction that some souls remember and "speak" (națaqa) about a previous life leads to the situation that de facto one ("present-life") singular human being claims to be another ("previous-life") human being. As a result, in case the previous-life identity of the soul can be identified, even if one identical soul is involved, the two different unique places in which the soul has manifested pull into different directions. What is personal identity under these circumstances? Where does an individual caught in such a situation belong to? It seems that this set of problems is clearly present in Druze discourse, either in the form of stories and testimony about ambivalent real-life experiences of double belonging, or in the form of general thoughts about inconsistencies and hard feelings that go along with conflicting forms of belonging. While many individual cases may be happy experiences, in the face of all the problems to be reckoned with, many Druze people seem to recommend stalling the "speaking" of children. 
Charakteristisch für das drusische Weltbild ist der Glaube an die „Transmigration der Seele“ (taqammuș). Nach dem drusischen Verständnis von Transmigration ist der Umgang mit einer Seele immer gleichbedeutend mit dem Umgang mit einem bestimmten Menschen, weil die Seele unmittelbar nach dem Tod des vorigen Körpers in einen neuen Körper wandert. Ist ein konkreter Mensch so zwar immer nur die vorübergehende Manifestation einer Seele, die irgendwo anders war und sein wird, ist doch der Sachverhalt ernst zu nehmen, dass es um konkrete Menschen geht. Die Vorstellung einer Wanderung der Seele zunächst beiseite lassend und unter Rückgriff auf den konzeptionellen Rahmen, der von Luc Boltanski in seiner Studie über die Abtreibung ausgearbeitet wurde, wird vorgeschlagen, dass diese Menschen nicht nur als Mitglieder von Gruppen und Objekten der Klassifikation betrachtet werden können, sondern darüber hinaus in ihrer Singularität. Singularität muss auf einen Menschen stets übertragen werden, und so wird die herausragende Bedeutung eines Singularisierungsprozesses deutlich, der vor der Geburt beginnt und das betreffende menschliche Wesen zu einem Namen und zu einem einzigartigen Platz in einer Familie hinlenkt. Aus der Perspektive der Vorstellung, dass Seelen wandern, stellt sich aber nicht nur die Frage, ob eine bestimmte Seele in ihren unterschiedlichen Erscheinungen Mitglied in derselben (konfessionellen, geschlechtlichen etc.) Gruppe ist; folgenreicher ist die Vorstellung, dass einige Seelen sich an ein früheres Leben erinnern und über dieses zu „sprechen“ (națaqa) beginnen. In dieser Situation behauptet de facto ein jetzt lebender singulärer Mensch, ein anderer zu sein. Wird also in drusischen Gemeinschaften die vorherige Identität der „sprechenden“ Seele tatsächlich identifiziert, so zeichnet ungeachtet dessen, dass nach drusischem Verständnis eine identische Seele involviert ist, die soziologische Tatsache, dass diese Seele notwendigerweise als zwei verschiedene und singuläre menschliche Wesen Teil der Welt ist, verantwortlich für einen oft als ambivalent erfahrenen Zusammenstoß unterschiedlicher Zugehörigkeiten.

\section{KEYWORDS}

Druze, transmigration, taqammuṣ, nuțq, reincarnation, personal identity; previous-life memories

Drusen, Transmigration, taqammuṣ, nuțq, Reinkarnation, personale Identität, Erinnerungen an ein Vorleben 


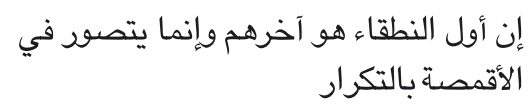

(Kitāb an-nuqaṭ wa-d-dawāir)

What I wish to underscore is the manner in which the body is often dismissed as carrying the properties of personal identity, whereas the soul is equated with a particular individual's identity and definitive state of self.

(Fishbane 2009: 392)

\section{INTRODUCTION ${ }^{1}$}

In the Druze ${ }^{2}$ communities of the Middle East, ${ }^{3}$ it is generally a part of their world view that eternal human souls ( $\operatorname{arwa} h$; sg. rūh) migrate from body to body until the end of times. ${ }^{4}$ As interview partners ${ }^{5}$ stated, referring to this

1 I would like to thank my colleagues Gebhard Fartacek and Daniel Mahoney for the comments and advice I received in the course of writing this article.

2 In this article, the designation of "Druze" is used, even though this religious community prefers al-Muwaḥhidūn, țā'ifat al-Muwaḥhidīn ad-Durūz, Banū Ma'rūf, or other designations.

3 In the Middle East, substantial numbers of Druze are found in Syria (mainly Jebel ad-Duruz area), Lebanon (mainly Chouf mountains, Southern Bekaa-valley around Hasbaya), the Golan, and Israel (Mount Carmel; area around Julis, area around Beit Jann). A small Druze community furthermore exists in Jordan (al-Azraq). For further background on the Druze see Swayd (2015); Firro (1992); Oppenheimer (1980); Bennett (1999); Rivoal (2000); Armanet (2011).

4 This article is based on the preliminary findings of the ongoing research project: StandAlone Project P28736 "Death \& Life: Local Conceptions of Reincarnation among the Druzes in the Middle East", funded by the Austrian Science Fund (FWF) and located at the Phonogrammarchiv (PhA) of the Austrian Academy of Sciences (OeAW); project team: Gebhard Fartacek and Lorenz Nigst (see <http://www.taqammus.at>).

5 Our empirical data has been collected through interviews with Druze from the Middle East, some of whom were reincarnated themselves. The interviews on which this particular article draws were conducted partly in Lebanon in autumn 2016, partly with interview partners who were Syrian refugees and had been granted asylum in Austria and Germany during the past three years. In cases of explicit consent of the interviewees, the interviews were recorded. All of the recorded interviews are continuously archived at and integrated in the collection of the Phonogrammarchiv of the Austrian Academy of Sciences. 
notion of the "transmigration of the souls" or "rebirth" (taqammuș), the Druze are "in a permanent state of recycling"; 6 they are forever "to be continued".7 As far as its propositional content is concerned, the Druze understanding of taqammus generally holds that everybody is subject to taqammuṣ - regardless of whether the reality of the phenomenon is recognised or not. ${ }^{8}$ More specifically, the human body is considered a "shirt" (qamīṣ), ${ }^{9}$ with the soul immediately putting on a new "shirt" when someone dies. Although the ascetic thrust of Druze religious poetry ${ }^{10}$ as well as normative statements may implicitly devalue the mortal body, it is always a body in and with which the soul "manifests" and by which it is "hidden" at the same time (see Seybold 1902: 30-31). ${ }^{11}$ This produces the effect that the dying breath of the individual from which the soul departs is thought to be the first breath of the newborn into which it moves. ${ }^{12}$ But, more importantly, it leads to the notion that the soul in each of its subsequent "life-circuits" or "generations" (ajyāl, sg. jīl) is a part of the world in the form of a distinct human being, with each of these human beings occupying a unique place in a (mostly) different familial group. The belief in taqammus therefore generally implies that the soul moves from household to household, cutting across the logic of descent in its journey through the "generations" (see Nigst, forthcoming). Normally, the present-life individual is thought not to have any concrete memories of his or her previous sojourn. That is, people generally hold that the same soul manifested as another human being in another family, but they normally do not know who that other human being was.

This article starts from the assumption that taking seriously the proposition that the soul always manifests in the form of a distinct human being allows for highlighting sets of problems that arise in the context of taqammus. More

6 Interview on 12/02/2017 in Vienna, Austria (PhA call number: 20170212.G001).

7 Interview on 24/10/2016 in Deir el-Qamar, Lebanon (PhA call number: 20161024.G001).

8 See <https://www.youtube.com/watch?v=fr5T4TTBr6w> (accessed 10/07/2017).

9 The Arabic term for "transmigration" (taqammuș) is derived from the same root as "shirt" (qamīṣ).

10 See e.g. the type of poem called nafsiyya, i.e. an admonitory poem directed toward the soul.

11 Body and soul thus inevitably form a unit (see Kastrinou 2016: 65-67); see also Kasamanie (2014: 98): "Metaphysically the 'personality' is the transcendent and permanent principle of the being, whereas the 'individuality' is only a transient and contingent manifestation of it."

12 See <https://www.youtube.com/watch?v=fr5T4TTBr6w> (accessed 10/07/2017); see also Armanet (2011: 150). This notion plays an important role in the discussion of concrete cases (see below), and respective discrepancies between date of death and date of birth not only need to be explained, but furthermore seem to be a major reason for skepticism. 
specifically, it suggests asking how human beings take their places in society and use this as an analytical framework for the discursive and social presence of migrating souls. It is suggested that Luc Boltanski's study on abortion (The Foetal Condition) with its focus on engendering- "that is, the creation of new human beings who come to take their places in a world inhabited by already-present living beings and also by the memory of the dead" (Boltanski 2013: 24)_offers important conceptual tools to explore this problem. Based on different manners of treating and considering human beings (ibid.: 24-28), Boltanski proposes a grammatical approach that identifies three specifications that must be respected if one wants to "make" a human being: "[...] the beings made must be recognizable as members of the human species"; they "must be susceptible to arrangement in classes"; and they must be "susceptible to singularization" (ibid.: 39). Subsequently, people do not just take their places in society because they are grasped by different categories and are members of groups, but each of them furthermore must "constitute a singular being, that is, a unique being for whom no other can be substituted" (ibid.: 28). Engendering thus requires "producing beings that can be singularized" (ibid.: 24). Processes of singularisation are essential for bringing about the personal identity of a human being, that is, the fact of being identified individually "without any possibility of being confused with another" (ibid.: 28-29). "[...] there is no society in which human beings are not objects of a process of singularization that assigns them one or more names designating them specifically as individuals, and that offers each one a unique place in an ordered set (most often in a kinship system)" (ibid.: 28). As such, processes of singularisation must be distinguished from the processes of forming a human being's social identity. These are not about bringing about a singular place, but about recognising that one has something in common with others or belongs to the same group (ibid.: 28-29). As a result, there are "two modes of grasping human beings in society", the "general" and the "singular" (ibid.: 35). Each human being is constantly associated with equivalence classes ("generalization") and singularised ("singularization")—-this is the way "social life shapes the human condition” (ibid.: 36).

Returning to the notion of a migrating soul at this place, taqammus could be seen to establish a tacit link between the distinct human beings that together constitute a given soul's trajectory through the "generations". Being the different manifestations of one identical soul, the human beings thus linked are more intimately related than the human beings between whom this particular soul has not migrated. It is with respect to this situation that characteristic sets of problems arise. This article suggests that they can be grasped more clearly 
by means of the above analytical framework because each of these human beings can be considered as a member of groups or categories and in his or her singularity.

Thus, on the one hand, the idea that every human being is only the current manifestation of a soul that used to be, and will be, somewhere else raises the question of which categories the soul was/will be a member in a previous/ future life. In fact, membership in categories is an important dimension of the Druze discourse on taqammuṣ because, even if people do not know from where to where a given soul moved in terms of concrete human beings, the question arises whether there is something to say about the categories. From where and to where does the soul migrate in terms of membership in categories? Are there any restrictions as to who at the local level may replace whom? Are there more clearly defined transmigration circles? Is there some predictability? Do the categories that inform and organise the local social world play a role? Which ones?

On the other hand, the notion of a line of distinct human beings who are the subsequent manifestations of one identical soul in the social world also implies that the soul in each "generation" occupies a singular position. That is, it manifests as a human being with a name and a unique place in a family-and it is here that other, more dramatic, questions arise. They concern the "generational" boundary which separates the distinct human beings which are the different manifestations of a soul in its subsequent "life-circuits". While this boundary normally makes knowledge of the respective previous sojourn impossible, can it become porous? (see Nigst, forthcoming). Although Druze discourse regarding the issue is far from homogeneous and there is room for scepticism, the Druze for the most part agree that, in some cases, children start to "speak" (națaqa) about a previous life in (mostly) another family - a life that almost always ended violently and "untimely". In the Druze perspective, such cases of "speaking” (nutq) indicate that a soul remembers its previous sojourn and "generation" and still claims to "be" its previous-life manifestation, that is, another distinct human being that already passed away. Who "is" the soul under these circumstances? Where does the concrete human being as which the soul manifests belong to in this case? This question becomes more critical considering that some instances of "speaking" actually lead back to the previous-life family of the "speaking" child. That family may recognise the child as the present-life manifestation of the same soul which previously manifested in their lost relative (i.e. the child may "retake" his or her previous-life singular position to an extent because the previous-life family recognises that he or she "is" their own lost relative). 
Such concrete cases of "speaking" raise many questions, most notably the question of the personal identity of the "speaking" individual. How is it even possible that the "speaking" child "is" another singular human being that has already passed away? ${ }^{13}$ How can someone be "one and two"? Is not the previous-life position-forever-reserved for the "previous-life" human being which has already passed away? What are the sociological consequences of a "retaken" previous place?

Everyone knows about "speaking” in the Druze communities, and it is part and parcel of the Druze understanding of taqammuṣ. This should not lead one to think, however, that everyone subscribes to the propositional content of taqammuș/nuțq, or has a consistent attitude (see Favret-Saada 2012). There is ample room for scepticism, and no one is forced to accept the concrete case of "speaking". At the same time, however, especially the fears which surface in the context of "speaking" children, the steps which people regularly recommend to take in the face of the phenomenon, or the hard feelings and conflicts of which they report, can not only be grasped more clearly if they are seen against the backdrop of the analytically identified problem of conflicting singular positions, but also give proof that people are aware of this problem. Pointing to that problem does not imply that it is all there is with respect to concrete cases of taqammuṣ. On the contrary, many families report unique and positive relationships between the "previous-life" and the "present-life" family.

\section{“TRANSMIGRATION CIRCLES"}

According to the analytical framework referred to above, the propositional content that souls migrate from body to body raises questions in respect of membership in classes. At a very high level of generalisation, the migration of the soul can be thought to take place between human body and human body. At this level, taqammus may not only be seen to encompass all human beings, but also to take place between all of them. The radius of the soul's migration and its field of movement are as wide as humankind itself, and the maximal unpredictability as to where (to which body) a soul will move next is tantamount to

13 Reincarnated individuals clearly speak about the "previous-life" individual in the first person singular: "This is me!”; “This is my mother"; "I did ...” (etc.). Likewise, family members of passed-away individuals say that XY “is" their passed-away relative. 
the equality of all humans. ${ }^{14}$ In contrast, the notion that human souls migrate into human bodies, however, is more often specified in important respects and creates some degree of predictability. In this context, membership in two categories or classes becomes crucial, with the respective specifications sometimes taking the form of veritable "transmigration circles": (1) ethnic-religious belonging or confession, and (2) sex or gender. Both seem to shape such transmigration circles and to influence into which circle a given soul's movement is channelled.

Druze often claim that Druze are always reborn as Druze. That is, "Druze" souls always migrate to "Druze" bodies-and only to "Druze" bodies. On the one hand, taqammuṣ implies that the movement of the soul (mostly) cuts across the boundaries of the individual familial groups and manifests in different families in its subsequent "generations" (see Nigst, forthcoming). On the other hand, Druze discourse uses that idea, and, by virtue of keeping taqammus within the boundaries of one's own collective, enables the production of an even more fundamental unity of the Druze collective. Not only are Druze literally "born in each other's houses" (see Oppenheimer 1980) and thus "related" through taqammus, but also the identical souls, who in the eleventh century AD sincerely responded to the call of the Druze missionaries, are still in circulation within the Druze collective. ${ }^{15}$ The link between confession and a characteristic and predictable movement of the soul also surfaces in other versions of such transmigration circles. According to some interview partners in Lebanon, who clearly rejected the idea, some Druze shaykhs hold that Christians are always reborn as Twelver Shiis (and vice versa), and Sunnis as Jews (and vice versa). More often, taqammus is thought to respect confessional belongings also in the case of those of other confessions. Christians are

14 This was sometimes stressed by our interview partners; see e.g.: "Taqammuș, according to what I think and according to my conviction, represents the unity of humankind ... what is it that differentiates human beings from each other [as human beings]? Neither religion, nor gender ... this is a man and that is a woman ... nor ethnicity ... this one over here is black and that one over there is white. None of this, not at all because the most important thing about a human being is the soul.” Interview on 04/04/2017 in Grieskirchen, Austria (PhA call number: 20170404.G001).

15 Many Druze regard endogamy as crucial because it guarantees that the souls continue migrating within the Druze community and supplies "pure" Druze bodies for the souls to wear. In her study of Israeli Druze communities, Armanet shows that the notion seems to be widespread that essentially "non-mixed" "Druze blood" has been-and has to be-kept "pure" and "clean". It goes hand in hand with the claim that the blood of the other confessions was more or less "mixed" (see Armanet 2011: 210-211); for discursive strategies to deal with individuals who violate the norm of endogamy see Rivoal (2000: 36). 
reborn as Christians, Twelver Shiis as Twelver Shiis, Sunnis as Sunnis (etc.). While some of our interview partners were highly critical of intraconfessional transmigration circles, and it is important to reflect on the political circumstances under which such ideas might gain in strength, ${ }^{16}$ the fact remains that the overwhelming majority of concrete cases of "speaking" occur within the boundaries of the Druze collective.

Membership in the categories "male" and "female" is equally as influential and effective when it comes to generating transmigration circles. Druze normally agree that the soul always migrates from a "male" body into a "male" body, or from a "female" body into a "female" body. ${ }^{17}$ Taken together, the simultaneous membership in these two categories (confession; gender) logically leads to the prevalent idea that Druze men are always reborn as Druze men, and Druze women as Druze women. Again, some of our interview partners were highly critical of such notions and mused whether such gender-based "transmigration circles" might be shattered in the future. It is striking to note the perception, however, that being a member of one's own confessional group is as deep-seated a membership as being a member of the categories "male" and "female".

Whichever criterion or set of criteria transmigration circles are based on, they presuppose that human beings are "capable of being arrayed in sets of the sort called categories or classes" that rest on an explicit or tacit principle of equivalence (Boltanski 2013: 26-27). The idea that Druze are reborn as Druze presupposes an equivalence of that sort-and thus possibility of replacement-within the category or class. Druze ideas centred on the notion of divine justice, however, seem to deny the notion of random replacement. A good example is the notion of "debt" (dayn), which rejects the idea of chance (see Armanet 2011: 217ff.). Random replacement was also regularly denied by our interview partners, no matter if they subscribed to confession and gender-based transmigration circles. On the contrary, their thoughts for the most part implied causal chains, which-due to transgressing the limits of an

16 Some of our Druze interview partners suggested that the different Middle Eastern states with a Druze population differed in that respect. For example, Syrian interview partners sometimes stressed the highly diverse confessional social reality of Lebanon ("Libnān ktīr ktīr țẩifī”) which made thinking along the lines of such confession-based transmigration circles more likely. It must be emphasised, however, that Lebanese publications about taqammuș specifically mention cross-confessional cases involving a transition from "Druze" to "Christian" and vice versa (see Laṭif 2014: 266ff.).

17 At least, people insist that all cases they know follow this pattern. 
individual lifetime-extended into an indefinite past. That opened up unlimited-but inexplorable-explanations for why the soul had moved to a particular place. Why is the individual sick in his or her current life? Why is he or she poor? These ideas were summarised succinctly by one of our interview partners by saying that human beings "made their own fate” (șāni 'li-qadaru)—i.e., they were engineering their own fate. ${ }^{18}$ The tacit link between the distinct human beings, with which the same soul is associated in its trajectory through the "generations", thus is the object of speculative thought and is regularly linked discursively to the problem of theodicy, whereby we have come across conflicting ideas as to how divine justice comes to pass-apart from the notion that people engineer their own fate, the notion occurs that every soul has to pass through all possible states (poverty, wealth, health, disease, etc.) in order for justice to prevail, that is, seemingly injust inequalities "make sense" against the backdrop of an alternative logic that reaches beyond the limits of an individual lifetime. ${ }^{19}$

\section{"SPEAKING": CONCRETE CASES OF TAQAMMUS}

Far from being merely propositional content, or an object of speculative thought or something people know about and can explain in abstract terms, taqammus flares up in the Druze communities in the form of concrete cases. Very widespread in the Druze communities, cases of "speaking" unfold in a fairly typical way (see French 2016; Dwairy 2006). Being an often unwanted, but fundamentally undeniable reality for the Druze, they characteristically begin when young children start to "speak" (națaqa) about a previous life in another family. Termed "speaking” (nuțq) in local parlance, the phenomenon is interpreted to be fundamentally about a soul that remembers a previous life (tadhakkara) which for the most part ended violently and unexpectedly (see Bennett 2006). ${ }^{20}$ While the soul has moved on, it is also still holding fast to

18 See the interview on 04/04/2017 in Grieskirchen, Austria (PhA call number: 20170404 G001).

19 See e.g. <https://www.youtube.com/watch?v=fr5T4TTBr6w> (accessed 10/07/2017); see also <https://www.youtube.com/watch?v=DzZbQp22R9A> (accessed 03/05/2017).

20 This is a fact not only underlined by the socio-anthropological literature, but also by our interview partners. They repeatedly emphasised that death had come to soon ("izā kēn il-umr zghïr") and was "violent" ('anïf) and "ugly" (bashi'). Interview on 17/10/2016 in Kfar Matta, Lebanon (PhA call number: 20161017.G001); see also e.g. the interview on 04/04/2017 in Grieskirchen, Austria (PhA call number: 20170404.G001). 
its previous "life-circuit", the life it had in and with its old body. In essence, "speaking” children, nāțiq (masc.) or nāțiqa (fem.) in Arabic, claim that they are someone else. While, at this level, one can still see a function and an effect in respect of the overall coherence of the Druze collective, the potential pressures on the real people involved are substantial-and it seems that, potentially, the very same problems which have been identified in analytical fashion further above become immediately relevant. These problems are, of course, not all that matters with respect to concrete cases of "speaking", but they surface in a variety of ways. As the locally used term "stories" (qișaș) concerning such concrete cases reflects, one essentially always has to do with retellings of what is said to have happened to concrete people; the individual "story" (qișșa) or "case" (hâala) may be told by the reborn individual him or herself, by family members, or by other people less involved.

According to the analytical framework outlined above, the way social life shapes the human condition essentially consists of a constant back-and-forth movement between the two operations of "generalization" and "singularization". The claim of being someone should therefore lead, at the same time, to dissonances in respect of the singular position and to "wrong" membership and misplacement within in the categories. In both respects, problems should arise. By virtue of bringing together two different human beings and lives (the "speaking" child and the adult this latter will eventually become on the one hand; the passed-away individual on the other hand), the soul not only "drags along" the name of the human being in which it manifested in the previous life, but also the categories that grasped that living human being. Hence various forms of dissonance and misplacement become uniquely meaningful in the context of "speaking". They are indicative of the process of taqammus, which in the majority of cases is not noticed because no "speaking” occurs. Accordingly, they play an important role in the plots that develop around the concrete cases of nutq. Here, not only do "speaking" children typically reject their proper name and insist that their family is not their real family, but characteristic forms of misplacement in respect to the categories surface with the "speaking" (for details see Nigst, forthcoming). In rare cases, such misplacement concerns the ethnic-religious or confessional belonging, such as the claim made to us by a Lebanese Druze grave-keeper in 2011 that a "Twelver Shii child was born into a Christian household and still behaved like a Twelver Shii child in that Christian household" (for cross-confessional cases see Lațif 2014: 266ff.). In contrast, other forms of misplacement, such as displacements between the categories of "adult" and "child", are frequent, and they are almost "built into" the situation brought about by nuțq because he or she who passed away as an "adult" by 
definition is reborn as a "child". ${ }^{21}$ Apart from misplacement in the age-categories, children may also suffer and be upset about having been transferred to another social class. ${ }^{22}$

\section{SINGULAR BEINGS}

While ethnographic evidence suggests that the soul's remembrance of its previous life is developed in poetic fashion even when no occurrence of nutq is involved, ${ }^{23}$ concrete cases of "speaking" are radically different from poetic developments of taqammus that involve no one in particular and refer to taqammus as an essentially silent and inscrutable process, or from taqammus in the sense of statements that concern the equivalence class ("Druze are reborn as Druze"): If there shall be "speaking", there has to be someone who actually "speaks"-and that someone "speaks" about a particular previous-life place. The cases of nutq are thus nothing less than the door through which taqammus is potentially pushed towards real and singular human beings with a name, a unique place-and feelings. Often, they are the human beings that populate one's own social world and life. At first, taqammuṣ involves singular beings only for the "speaking" child and his or her family, and amounts to nothing more than dreamlike traces of memories. But things potentially gain momentum. If nutq is not just a flaring up of memories that can be "roped in" by making the child forget those memories, then it may actually lead to the identification of the previous-life family of the "speaking" child and to the recognition of the child by his or her previous-life family (or individual members of that family). Hence the "speaking" can unfold its full creative force, and to a certain extent it can make the child "re-take” his or her previous-life position.

21 The Druze are highly aware of this consequence of their belief-system; see Armanet (2011: 151-152) and Lațif (2014: 194) as well as the interview on 03/10/2016 in Vienna, Austria (PhA call number: 20161003.G001].

22 In a 2016 article for the Lebanese newspaper An-Nahār, Salwa Abou Chacra quotes the remarks of a woman who spoke about her reincarnated mother. The mother felt lost because in her previous life she had designed the clothes of Șabāh (i.e. the Lebanese singer and actress) and lived a life of opulence. In her current life, however, she is poor and wants to forget because, despite loving the people in both worlds, she cannot reconcile them with each other; see <https://www.annahar.com/article/395204> (accessed 29/11/2016) and also <https://www.youtube.com/watch?v=0_v2Pb9jopo> (accessed 19/05/2017; from min. 16:20) as well as the interview on 13/02/2017 in Vienna, Austria (PhA call number: 20170213.L001).

23 For example, taqammuș is linked with the notion of "exile", and people imagine the pain caused to the soul by having to leave its old house which is compared to the pain felt by "brides" (see Armanet 2011: 248). 
"Speaking” thus potentially forces proximity on hitherto unrelated families. An entire life and those who populated that life may reappear, that is, those who belonged to the child in his or her previous life because the child belonged to them-also a highly complex emotional situation. All of a sudden, the inability to tell which soul has reincarnated in which body is replaced by the immediacy of real human beings. It is precisely for this reason why occurrences of nuț are so ambivalent and so unclear with respect to their potential outcome at the beginning and why families sometimes seem to be dreading the considerable creative and relationship-forming force contained in an instance of "speaking" (see Nigst, forthcoming). The result may be desirable, but it may also be not desirable. The analytically identified sets of problems, and most notably the problem of conflicting singular positions (see below), are not everything that matters in a concrete case, but people do consider them, and they do surface.

\section{THE ASCERTAINMENT OF THE PREVIOUS-LIFE PERSONAL IDENTITY}

The ascertaining of the "speaking” child's previous-life personal identity cannot be complete until the family of the passed-away individual recognises and confirms that the "speaking" child in fact "is" their lost relative in a different bodily shape (qamīṣ; qālib). That recognition, however, requires "proof” (ithbātāt; adilla), and the claim of the "speaking" child is immediately met with the prompt to "give proof" (which does not necessarily convince everyone) ${ }^{24}$ It is only contingent on that proof that the child may, to a certain extent, "re-take" his or her unique previous-life place. This proof is demanded from the "speaking" child (or from an adult later in life) ${ }^{25}$ because it is that proof which substantiates an otherwise relatively arbitrary claim. ${ }^{26}$ From the Druze

24 See e.g. the interview on 24/10/2016 in Deir el-Qamar, Lebanon (PhA call number: 20161024. G001).

25 According to our interview partners, "speaking” children are often made to forget in their childhood, but stumble across their previous life as adults again or intentionally seek out their previous-life families later in life. Evidently, they also have to offer proof when they are already adults.

26 It is worthwhile stressing that the Druze scriptures clearly document doubts in respect of the soul's movement from body to body. More specifically, the Kitāb an-nuqaț wa-d-dawä'ir expressly offers arguments meant to dissipate such doubt. The prime cause underlying such doubt is explicitly given: "In case you say: What is the proof that it [i.e. the soul] migrates from body to body when this is an indiscernible process which cannot be perceived or observed with one's own eyes, you must know that ..." (cf. Seybold 1902: 32). The absence of any observable process also underlies the need for "proofs", which is such a common element in the recounts of concrete cases of nuțq | taqammuṣ. 
perspective, the claim that one singular being in essence "is" another singular being, is far from being something that simply can be made-one example of how the analytically identified problem of conflicting singular places surfaces. Accordingly, the retelling of how that proof is actually given by the "speaking" child is an integral dimension of the Druze discourse on nutq. ${ }^{27}$ The retelling characteristically describes how (or at least: that) the previous-life family of the child was eventually identified, and how the "speaking" child was either taken to its previous-life family or how individual members of the previous-life family sought out the child when the news of his or her "speaking” had begun to spread. ${ }^{28}$ The data collected for this research project point to the existence of virtual topoi in the retellings in the context of giving proof. Thus, apart from deliberate but unsuccessful attempts to trick the child, such as taking him or her to the wrong house (see also French 2016), the "speaking" children identify their previous-life family members either in person or in photographs. A frequent topos is knowledge on the part of the "speaking" child of things that no one except for the previous-life individual could possibly have known. Such knowledge characteristically refers to hidden objects (money, gold, weapons) or to what an interview partner called the "secrets of the family" ("asrār al-ấ'ila"). ${ }^{29}$ Thus, for example, the "speaking” children may mention children who passed away right after birth and whose existence is only known to the immediate family; they may speak about secrets among the family members of the previous-life family; they may describe affairs, beauty marks, etc. Another common element in the retelling of how proof was given is the child's knowledge of the path that leads to the previous-life family's house or about amendments made to their house (e.g. added rooms, shifted doors, removed water boilers, etc.). In more than one instance, our interview partners furthermore reported about "speaking” children who could name the people who

27 They have been discussed extensively in the literature; see Dwairy (2006), Stevenson \& Haraldsson (2003), French (2016).

28 See for example <http://www.aljoumhouria.com/pages/view/19492/2799> (accessed 19/05/2017): “[...] 'Once, I heard that my son's soul had reincarnated in the body of a boy from the Zahlān family in 'Ālayh, so I went there with my husband pretending that we wanted to sell them some book for children, but it quickly became clear to me that their son had been born before my son's death.' That was not the only time when Randā [i.e. the mother that actively seeks to find her lost son] returned home disappointed. Thus, another time she visited the house of the Abū Rāfí family in Bsatine area after she had heard that they had a son who was very fond of dancing with the sword and the shield, just like her son Râ'id. She hastened to see them pretending that she wanted to rent a flat, but when she saw the boy, it did not click-she was not emotionally touched by him, and he on his part did not remember her."

29 Interview on 02/13/2017 in Vienna, Austria (PhA call number: 20170213.L001). 
were present at the moment of their death and allegedly could reproduce the sentences those individuals said. The retelling of how "speaking” Druze children prove that they really "are" the passed-away individual they claim to be, are often said to have been pretty impressive performances. Time and again, people describe how "speaking” children enter a house, know where everything is, easily identify the individuals present, and lead to the hidden objects, etc. If the proof given is confirmed by the family of the passed-away individual, then the reborn individual may, in addition to his or her present-life singular position, "re-take" the position that he or she had in the previous life. Conversely, the previous-life family may accept the child as the reincarnation of their lost relative, although family members may disagree. This can be expressed by means of a celebration. ${ }^{30}$ As one of our interview partners explained, in this case, the individual in question "continues with his [previous] life as if he had not died (biykammil w-ka-annu mā zāl 'âyish), and they regard him as the other one [who has passed away]". ${ }^{31}$ Such relationships can be happy and fulfilling, and, in fact, Druze people for the most part emphasise that the phenomenon is overall positive. In case relationships develop, this may lead to the reborn individual receiving inheritance or financial support and to his or her ritual inclusion as the previous-life individual. ${ }^{32}$ The extent to which taqammus and "speaking” establishes lasting relationships between families varies. Our data suggest that some such relationships span more than one generation.

In any case, the existence of happy and fulfilling taqammus-based relationships does not rule out that there is ample room for-intrapersonal and interpersonal—conflict linked, most notably, to the question of singularity.

\section{CONFLICTING PROCESSES OF SINGULARISATION}

Once an occurrence of "speaking" has really led to the "reintegration" of the child in his or her previous-life family, this implies that the reborn individual now somehow occupies two unique positions in two different familial groups.

30 See Dwairy (2006: 35): “The whole past-life extended family came to us, kissed him [i.e. the boy who is accepted as the reincarnation] and invited him into their home ... When we went to their place it turned out that they had arranged a big party and invited all the family and neighbors. It was like a marriage feast. His past-life sons [16 to 21 years old] carried him [five years old] on their shoulders all around the village, saying that he was their father [...].” 31 Interview on 04/04/2017 in Grieskirchen, Austria (PhA call number: 20170404.G001).

32 The inclusion of the reborn children in wedding ceremonies seems to be common. Thus, for example, a child may take the position of a passed-away father. 
Even if the "previous-life"-family recognises that the child (i.e. the soul) does have a new life, the contact fundamentally rests on the notion that a passedaway individual "is" another concrete human being. This becomes a reality fraught with sociological contradictions and possible (emotional) conflict because two social realities pull into two different directions. In contrast to the abstract notion that "souls move from body to body", things become potentially much more troubled as soon as singular human beings and singular positions are involved.

To further analyse this fraught reality, it is worthwhile to turn back to Luc Boltanski. In his work, he approaches the processes of singularisation through acts of engendering which are "responsible for bringing new human beings into the social world [...]” (Boltanski 2013: 29). Consequently, "the singularization of human beings occurs in the course of a process involving conception, pregnancy, birth, integration into a social group and subsequent phases of socialization [...]" (ibid.), and human beings "inscribed in flesh" "must be taken up again in a symbolic mode, that is, in speech [...] in order to become singular beings." Being fully human thus requires engendering "through speech" and "through flesh" (ibid.: 37-41). Without confirmation "by speech", the singularity necessary for their recognition as human beings cannot be conferred upon them (ibid.: 47). Singularisation must thus always be transmitted (ibid.) by another singularised human being. The confirmation by speech and the "adoption" by the mother of the developing human being initiate the process of singularisation (ibid.: 49):

These beings are referred to an origin, oriented towards a place, prepared to receive a name that awaits them, and so on. In this sense, the mother's confirmation of the humanity of the being taking shape within her anticipates and prepares the way for the child's access, after birth, to a singular position in society.

Returning to cases of "speaking", according to the requirements expounded by Boltanski, the human beings involved in the concrete case are singular and both human "through flesh" and "through speech". The child, and the adult he or she will eventually be, has been recognised and inserted into the collective where he or she occupies a unique position; and the passed-away individual whose place is "retaken" likewise was human "through speech" and occupied, and still occupies, a unique position and was inserted into the collective and into symbolic relations. Thus, if concrete cases of "speaking" involve human beings who long for-and to a certain extent may come to retake-the places in the social world that constituted their previous life, they should be faced with the sizeable problem that, literally, a "clashing of two worlds" 
(Bennett 1999: 104) ${ }^{33}$ is involved. Singularity has been transmitted to the passed-away individual (A), and the individual was subject to a process of singularisation that oriented him or her towards a place and prepared him or her to receive a name; and the same holds true for the child-and eventually adult-(B) who claims to be (A). If one thus pushes further the analysis of the fact of singular human beings that follows from the notion that the soul always manifests in the form of a concrete human being, clear problems begin to show, to which Druze regularly point. Thus, many people emphasise that, as a result of this pulling into two different directions, the reborn individual becomes like two personalities and is potentially left behind in a thoroughly inconsistent situation which our interview partners did not consider a good and preferable option for growing up (see Nigst, forthcoming). Furthermore, even if Druze discourse insists that the child is only a guest in one's household who is exiled from "house" to "house" (see Armanet 2011: 151-152), in the context of a case of "speaking”, the objectively conflicting form of belonging may cause pain and hurt feelings for those in whose fold the child has been born. More specifically, the relocation of the entity which "originates in speech" (see Boltanski 2013: 45) with another family can not only lead to the notion to have "found" a lost family member again, but also to the impression on the part of the present-life family to have partially "lost" their own child. Our interview partners repeatedly implied that families were not interested in their child belonging to another family apart from themselves, and they pointed to the potentially painful situation where a mother who loves her child feels that the child has become the child of another woman. ${ }^{34}$ Distressed by the pull of the previous-life world on their child, the situation may lead to substantial animosities. ${ }^{35}$ It is striking

33 That "clash" should not be exaggerated; indeed, some of our interview partners suggested that the problems involved were not a big scandal.

34 See Nigst (forthcoming), Dwairy (2006: 35) as well as the interview on 13/02/2017 in Vienna, Austria (PhA call number: 20170213.L001).

35 A passage from an article in Al-Joumhouria newspaper illustrates such animosities: "In view of the enormous joy displayed by Rībāl [i.e. the "speaking” boy] and his strong desire to return and live with his old family, Randā [i.e. the previous-life mother] was aware of his mother's fear of losing her son, but she did not succeed in reassuring her that she was not going to take Rībāl away from her and would be satisfied by taking care of him only from afar; after three months of happiness and after the spirit had returned to Randā, she found herself 'devastated': 'Rībāl's mother started to restrict my visits and accused me of seducing him with gifts until she finally forbade me to come and visit at all and thought about changing her place of residence.' [...].” See <http://www.aljoumhouria.com/pages/view/19492/2799> (accessed 19/05/2017). 
how powerful the entity that "originates in speech" really is: the children are "found" and "lost" through "speech". This also manifests in cases where the previous-life family rejects the "speaking” child. Here, the recognition that the "speaking" child "is" the passed-away relative is not given. ${ }^{36}$ Such a rejection in the end refers the "speaking" child back to an unnameable previous-life place within the equivalence class and transmigration circle. Under these circumstances, the child cannot be pulled back into the singularisation process that turned the passed-away individual into the person he or she was. This, however, also implies that the case of "speaking" cannot really come to an end, and a rejection may bestow something "illegitimate" on the human being in question, a feeling or suspicion of inadequacy. In contrast, some individuals may not dare to seek out the previous-life place, maybe because they fear that feeling of inadequacy, or maybe because they are afraid of the responsibilities that might arise from a "re-taken" previous-life position. In cases of such avoidance, there seems to be a certain restlessness, and the previous life has something secretive about it. ${ }^{37}$

\section{DIFFERENT BODIES AND STILL THE SAME?}

Cases of "speaking" where the previous-life identity of the "speaking" child has been identified furthermore require coming to terms with the fact that, by definition, bodies are involved. The passed-away singular human being had a body, and so does the reborn individual. Within the logic of a concrete case, the families necessarily have to come to terms with the idea that a body is not quite "theirs" alone anymore or, in the case of the previous-life family, accept the loss of the body of their lost relative. But it was that "body" in which that family member lived his or her real life; it was that body that was part

36 The family of a "speaking" child who was rejected by the previous-life family may still involve that family in a different way: "According to K's mother, her son was rejected [by the 'previous-life' family] because of his dark skin, as opposed to the fair skin and blue eyes of the lost son of the past life family” (Dwairy 2006: 41-42).

37 See e.g. the interview on 26/10/2016 in Deir el-Qamar, Lebanon (PhA call number: 20161026. G001). 
of their shared life. Again, it is not implausible to come across statements that specifically refer to the difficulty of accepting a different body as the beloved lost relative (see e.g. Stemman 2012: 204). ${ }^{38}$ Needless to say, there are also people who reject altogether the idea that someone could literally retake their beloved relative's unique position and replace the full human being whom they loved. They seem to reject the idea that identity of the soul translates into identity of the entire person. Thus, in an article published in Al-Joumhouria newspaper, a mother who was approached by a family with a "speaking" child claiming to "be" her passed-away son Mu'īn is quoted with the words: "Mu'īn is irreplaceable, and time won't bring him back." ${ }^{39}$ On the other hand, the reborn individual "retakes" his or her unique previous-life position in the capacity of being a lived body. He or she has to deal with the fact that their concrete case of taqammus has repercussions on the level of the lived body. These repercussions most certainly can be joyful, but they do not have to be. It is all but a surprise that individuals who are recognised by their previouslife families may have the feeling that the space of their lived body-their "private sphere"- is being encroached upon (see Gugutzer 2001). Thus, for example, the recognition on the part of the previous-life family may force specific forms of ambivalent intimacy upon the lived body of the reborn individual (see Nigst, forthcoming). ${ }^{40}$

\section{SOMETHING THAT JUST HAPPENS}

According to the Druze, "speaking” by essence is unintentional, and taqammus is an empirical process to which everyone is subjected. This view may lead far beyond the terms of the taqammus discourse proper and even de facto reject the religiously informed meanings and instead fathom taqammuṣ in

38 In this context, expressions that refer to the different form are common (see e.g. bi-qālib ākhar; bi-jasad ākhar).

39 See <http://www.aljoumhouria.com/pages/view/19492/2799> (accessed 19/05/2017): "Muīn lā yuqaddar bi-thaman wa-lan yukarrirahū z-zaman.”

40 See also the interview on 17/10/2016, Kfar Matta, Lebanon (PhA call number: 20161017. G001). 
terms of the "natural sciences". ${ }^{41}$ Nuṭq is simply the moment where taqammus flares up. Significantly, according to our interview partners, it is concrete cases of "speaking" that might cause or reinforce belief, but it is certainly not belief that causes the concrete cases. As our interview partners insisted, even their Christian neighbours or atheists would not deny that taqammus really existed-taqammuṣ happens, however people understand it and regardless of what they think of it. ${ }^{42}$ Thus, for example, one interview partner stressed that many Christians from Suwayda' in Syria believed in taqammuṣ because they were confronted with it in the sense of a reality on an almost daily basis. They even tell about Christian neighbours and friends who quickly silenced their children. Again and again, it was stressed that it was the concrete cases (hâlāt) that mattered because it was those cases that unfolded in front of people's eyes and that they experienced. ${ }^{43}$ "Personal experience" (tajriba) is a recurring lexeme. ${ }^{44}$ As one interview partner put it, belief in taqammuṣ in this very

41 Such understandings of taqammus are a more common dimension of the discourse on taqammus than might be expected. It seems that many educated people find it hard to generally subscribe to the propositional content of taqammus, or at least not in any context. In exemplary fashion, one interview partner compared "rūḥ" to "energy" (țāqa). The idea behind it was that keeping with "something scientific close to taqammuṣ" (shī 'ilmī qarīb la-t-taqammuș) that could be understood "one-hundred percent” would help to develop an understanding of taqammus that was more in line with their own convictions. As regards the association of "rūh" and "energy" (tāqa ), he stated that, according to the religious understanding, "that energy—or that 'rūh'—does not change ... that is, it does not change its form; it leaves your body and stays the same, and this 'rūh' migrates just like it is to another body." Thus, according to him, Druze religion (ad-dīn ad-dirzī) says that "energy preserves its form (bithāafiz 'alā shakla) and it is the latter which is called 'rūh' and that 'migrates' to a different body." Referring to the law of conservation of energy, he pointed out that science, on the contrary, taught that energy could not get lost but only change its form; it told us that energy had "the freedom to choose the form" (innu hāy aț-țāqa 'andhā hurriyyit ikhtiyār ish-shakl). But that turning of energy from one form into another-whatever form that may be-was, according to this interview partner, precisely what taqammuṣ was (huwe b-hadd dhätih huwe t-taqammuș). Thus, according to this interview partner, the "huge difference" (mufäraqa kbīre) between the religious and the scientific understanding was between the scientific teaching that energy changed its form and the religious teaching that it did not. But according to him, regardless of how taqammuș - understood in this wide sense-was explained, things "in the end discharged into the same view" (biyșubb bi-nafs il-madhhab bi-n-nihāya), i. e. came to the same thing. Against the backdrop of a thus transformed notion of taqammus that has been "translated" into more acceptable terms, the interview partner stressed that what he really "rejected one-hundred percent" (illi aruddu tamäman) was the denial of the existence of taqammuṣ. See the interview on 12/02/2017 in Vienna, Austria (PhA call number: 20170212.G001).

42 See e.g. the interview on 12/02/2017 in Vienna, Austria (PhA call number: 201702012.G001).

43 "Naḥnu nu'min ka-mujtama' bi-shakl 'āmm bi-t-taqammuṣ min khilāl waqā'i' shāhadahā l-mujtama' wa-ra'āhā l-mujtama." See the interview on 13/02/2017 in Vienna, Austria (PhA call number: 20170213.L001).

44 See also <https://www.youtube.com/watch?v=uN4levEgl0Y> (accessed 11/07/2017). 
matter-of-fact-like sense is more or less tantamount to "not being able to deny taqammuș". In a noteworthy passage, he remarked: "If you'd go out there in Suwayda' and claim that taqammus does not exist, even if you'd produce all the evidence in the world that'd allow you to prove that taqammuṣ doesn't exist, there is no way that people are going to believe you, because people have witnessed and lived this in the sense of a palpable experience (tajriba malmūsa); something material and palpable (shī māddī malmūs)." ${ }^{\prime 5}$ It is thus quite understandable why the "speaking" of Druze children about a previous life is so crucial for the everyday-life experience of taqammuṣ.

\section{SPEAKING, SILENCING, AND FORGETTING}

In view of the difficulties that may go along with the instances of "speaking", and considering the fact that for the Druze, "speaking" occurs irrespective of one's will, it seems plausible, however, that many people try to "silence" (sakkata) their "speaking” children and "make them forget” (ansā) the memories they have of a previous life (see Nigst, forthcoming). Many people tell that they "tried" to speak when they were young, but their families prevented them from doing so ("ahlī mana'ūnì 'an il-kalām"; "ahlì sakkatūnī”). ${ }^{46}$ This is not to suggest that everybody would recommend forcing "speaking" children to "shut up", but it remains significant that an entire discourse on "speaking" is interfused with the notion of "silencing" and the idea that children should maybe best forget about their previous lives. When they think about and discuss the phenomenon of "speaking", people constantly suggest that they would not let their own children "speak". Especially the announcement to "silence" one's own children, should they start to "speak" in the future, seems to illustrate well how much the problems that one can highlight in an analytical fashion are present in people's thoughts. In fact, it is a serious flaw of much of the secondary literature about taqammus that it focuses almost exclusively on those cases where contact with the previous-life family has actually been established, and rarely ever considers that nuṭq at first is the possibility of such a contact-a possibility that some people want to prevent from becoming reality because it is intimately a cause of uncertainty (see Nigst, forthcoming). In the context

45 See the interview on 12/02/2017 in Vienna, Austria (PhA call number: 20170212.G001). 46 See the interview on 13/02/2017 in Vienna, Austria (PhA call number: 20170213.L001). 
of "silencing", it must furthermore be underlined that the Druze notion of the migration of the soul from body to body, generally speaking (i.e. even without the occurrence of nutq), involves the more complex perception of a gradual detachment of the soul from what is decidedly more than just a mortal body, but the entire life of a human being; a gradual loosening and attenuating of everything that made up the previous place; the previous Lebenswelt and the previous existence as a particular human being. ${ }^{47}$ It is only with time that those memories are said to fade away. This perception of a gradual detachment also occurs forcefully in the context of nutq and the concrete cases. As our interview partners repeatedly explained, the memories of the "speaking" child that surface through an instance of nutq are bound to weaken in time, and the children are likely to forget them by and by, even if the previous-life family has been identified. Thus, if the parents actively "silence" their children, they forestall, as it were, something that in all probability would have happened by itself. In case the memories do in fact lead to real contact with the more circumscribed social world of the previous life, however, the families often seem to allow for some flexibility with regard to the "speaking" child's sense of belonging and accept that the child emerges in its previous-life social space and-maybedisappears from it again in time (see Robertson 2011). In the everyday life of the Druze communities, children who, according to the emic outlook, are still yearning for those to whom they remember having belonged in their previous life, are often treated with considerable warmth and generosity. Syrian interview partners have told us about a boy who goes to school in the town of Salkhad and every single day visits his previous-life family and spends long hours sitting silently in the presence of those who were part of his previous life and whom he still loves. Even if the family does not feel the same way-after all, it is not them who remember a previous life, but the boy-they feel empathy with the boy's troubled soul and just let him be "at home”. One cannot but agree with the interview partner, who called this "lovely" (shī ḥelu). ${ }^{48}$

47 Newborn children are also considered "strangers" who have an adult soul that had been with other people in a different place as another human being. The idea of a more or less painful departure of the soul from what used to be its life can thereby be envisioned in the form of all sorts of "popular wisdom" that conjectures about the unknown past of a particular soul; for example, people pay attention to the hands of the newborn (see Armanet 2011: 151-152). Similar popular wisdom was often mentioned by our interview partners; see Nigst (forthcoming): footnote 18.

48 See the interview on 04/04/2017 in Grieskirchen, Austria (PhA call number: 20170404. G001). 
It seems, however, that despite the experience of enriching and joyful nutqbased relationships, people are often worried about negative consequences of cases of "speaking" which fully unfold. They often point to the fact that only the present life is pertinent and topical. The human beings involved and their lives are not the same:

The reborn individual (mutaqammiș) remembers some things [from the previous life]. He does not remember everything in the sense that he would live his old personality (shakhșu al-qadìm): He lives his new personality (shakhșu al-jadìd), and thereby remembers that he was this and that person, and that he was so and so, some things, but he thinks in a new way (biyfakkir bi-țariqa jdìda), he lives his new personality (biyìish shakhșu l-jdìd). ${ }^{49}$

Accordingly, they suggest that the parents have to take care that the child can live his or her present life unhindered. Significantly, this involves keeping away from the child those who can orientate the child towards a different singular place: "They do not let him go and get to know his previous-life family." 50 To put it in more analytical terms, that anachronistic singular place must not encroach on the singular human being of this present life by means of "re-activating" the processes of singularisation that brought about the passed-away singular being. The present-life family shields their child from being exposed to a form of belonging which is outdated (see Nigst, forthcoming).

\section{CONCLUSION}

According to the propositional content of the belief in transmigration, the bodies into which a given soul subsequently moves during the process of taqammus are only different manifestations of that soul which in itself remains identical. Considering, however, that the souls are thought to move on to the next body immediately after death, one is always dealing with distinct human beings who have necessarily taken their singular places within families. None of this poses a problem as long as the individual "generations" are separated, that is, as long as the singular places associated with two distinct manifestations do not orientate one identical soul to two different places in two different families at the same time. Precisely that, however, potentially happens in cases of "speaking” (nuț) which correspond to the idea that a soul "speaks" about a previous life to which

49 See the interview on 13/02/2017 in Vienna, Austria [PhA call number: 20170213.L001].

50 See the interview on 04/04/2017 in Grieskirchen, Austria [PhA call number: 20170404.G001]. 
it still holds fast. What makes such cases potentially difficult is that a "speaking" soul manifests as a distinct human being that belongs to particular people. If the "soul" claims to be someone else, then it is that distinct human being, which is the soul's present manifestation, who claims to be someone else. In Druze communities in the Middle East, there are instances of "speaking” that actually lead back to the previous-life identity of the "speaking" soul. The "speaking" child is sometimes allowed, to an extent, to "re-take" the previous-life place. While this may lead to the establishment of intimate and lasting relationships between families that, according to the idea of taqammuṣ, are not based on the normal "man-made" forms of political interest, problems may still arise. As a matter of fact, the pressures potentially exerted on the personal identity of the "speaking" child and the resulting inconsistencies are easily imaginable-and it seems that the Druze themselves constantly imagine them. In fact, problems of conflicting belonging not only surface in the form of testimonies about respective real-life experiences, but also in the form of fears that come before the experience, or in the shape of general strategies which people hold ready for the case that "speaking" affects their own lives. Those problems seems to be a general background, whether parents "silence" their "speaking" child and thus prevent their child (i.e. the soul) from being grabbed by the pull of a competing familial belonging, whether they let their child "speak" within the walls of their own house, but avoid establishing contact with the "previous-life" family, or whether they accept that their child may feel a different form of belonging which may last or fade away with time, thus allowing their child to emerge and maybe disappear in a different familial environment. It is important not to forget in this context that, while the family of the "speaking" child may feel threatened by, or at least ambivalent about, the pull exerted by others on their child, for those to whom the soul, which is hidden behind the "speaking" child, belonged in its previous life, finding that soul again may be comforting. For them, the "speaking" child manifests the same soul that they loved as another distinct human, and which they lost to tragic death, which may fill the painful void the passed-away relative left behind. In any case, "speaking” is not simply something "easy", and it is certainly not simply “about happy reunions” (Bennett 1999: 103). Cases of “speaking” can be such happy reunions, but, at the same time, they are difficult in many respects.

Not least, cases of "speaking" are interesting because, both in their happy and in their difficult dimension, they seem to corroborate in unique fashion that human beings do not simply have their singular place, but that singularity has been transmitted to them. Nowhere does that show more clearly than in the situation where two places are bestowed on one human being, and where a human being somehow "is" one and two. 


\section{REFERENCES}

Armanet, Éléonore. 2011. Le ferment et la grâce: Une ethnographie du sacré chez les Druzes d'Israël. Toulouse: Universitaires du Mirail.

Bennett, Anne. 1999. "Reincarnation, Marriage, and Memory: Negotiating Sectarian Identity among the Druze of Syria”. Dissertation Submitted to the Faculty of the Department of Anthropology, University of Arizona.

Bennett, Anne. 2006. "Reincarnation, Sect Unity and Identity among the Druze". Ethnology 45: 87-104.

Boltanski, Luc. 2013. The Foetal Condition. A Sociology of Engendering and Abortion. Cambridge \& Malden: Polity Press.

De Smet, Daniel. 2007. Les Épîtres sacrées des Druzes: Rasā’il al-Hikma, vols. 1 et 2: Introduction, édition critique et traduction annotée des traités attribués à Hamza b. 'Alì et Ismāî̀l at-Tamīmì. Leuven: Peeters.

Dwairy, Marwan. 2006. "The psychological function of reincarnation among Druze in Israel”. Culture, Medicine and Psychiatry 30: 29-53.

Favret-Saada, Jeanne. 2012. "Death at your heels: When ethnographic writing propagates the force of witchcraft”. Journal of Ethnographic Theory 2 (1): 45-53.

Firro, Kais. 1992. A history of the Druzes. (Handbook of Oriental Studies, Sect. 1). Leiden etc.: Brill.

Fishbane, Eitan P. 2009. "A Chariot for the Shekhinah: Identity and the Ideal Life in Sixteenth-Century Kabbalah”. The Journal of Religious Ethics 37 (3): 385-418.

French, Christopher. 2016. “Reincarnation Claims”. In: Groome, D. \& R. Roberts (eds). Parapsychology: The Science of Unusual Experience. London: Psychology Press, 82-95.

Gugutzer, Robert. 2001. “Grenzerfahrungen: zur Bedeutung von Leib und Körper für die personale Identität”. Psychologie und Gesellschaftskritik 25 (1): 69-102.

Kasamanie, Adnan. 2014. Druze Cosmology. Bakaata: Maarad Al Shouf Al Daem Lil Kitab.

Kastrinou, Maria. 2016. Power, sect and state in Syria: The politics of marriage and identity amongst the Druze. London: I.B. Tauris \& Co.

Lațīf, Lațīf Ilyās. 2014. At-Taqammuṣ wa-tadhakkur al-hayāt as-sābiqa: intiqāl al-rūḥ am adh-dhākira? Aț-țab‘a al-ūlā. Bayrūt: Lațîf Ilyās Lațīf.

Nigst, Lorenz (forthcoming). "Entering a Gigantic Maze: The Ambivalent Presence of Previous-Life Memories in Druze Discourse”.

Oppenheimer, Jonathan W.S. 1980. “We Are Born in Each Others' Houses”: Communal and Patrilineal Ideologies in Druze Village Religion and Social Structure”. American Ethnologist 7 (4): 621-636. 
Rivoal, Isabelle. 2000. Le maîtres du secret: Ordre mondain et ordre religieux dans la communauté druze en Israël. Paris: Éditions de l'École des Hautes Études en Sciences Sociales.

Robertson, Alexander F. 2011. "How can Lukoho be his own grandfather? Being and becoming in the Cartesian gap”. Journal of the Royal Anthropological Institute 17: 585-603.

Seybold, Christian. 1902. Die Drusenschrift: Kitāb Alnoqaț Waldawāir. Das Buch der Punkte und Kreise. Leipzig: Kirchhain N.L.: Schmersow.

Stemman, Roy. 2012. The Big Book of Reincarnation. Examining the Evidence That We Have All Lived Before. San Antonio: Hierophant Publishing.

Stevenson, Ian \& Erlendur Haraldsson. 2003: "The Similarity of Features of Reincarnation Type Cases over Many Years: A Third Study”. Journal of Scientific Exploration 17 (2): 283-289.

Swayd, Samy. 2015. A Historical Dictionary of the Druzes. $2^{\text {nd }}$ ed. Lanham etc.: Rowman \& Littlefield.

Ṭalī, Amīn 2001. At-Taqammuṣ. Aț-țab‘a ath-thāniya. Buq‘āta: Mariọ ash-shūf ad-dā’im li-l-kitāb.

\section{ONLINE SOURCES}

$<$ https://www.youtube.com/watch?v=fr5T4TTBr6w> (07/10/2017)

$<$ https://www.youtube.com/watch?v=DzZbQp22R9A> (05/03/2017)

$<$ https://www.youtube.com/watch?v=0_v2Pb9jopo> (19/05/2017)

$<$ https://www.annahar.com/article/395204> (29/11/2016)

$<$ http://www.aljoumhouria.com/pages/view/19492/2799> (19/05/2017)

$<$ https://www.youtube.com/watch?v=uN4levEgl0Y> (07/11/2017)

Lorenz NIGST

Phonogrammarchiv - Österreichische Akademie der Wissenschaften

http://www.phonogrammarchiv.at

lorenz.nigst@oeaw.ac.at

doi: 10.1553//jpa8s56-81 